\title{
Local Government Under Army Rule: A Comparative Analysis of Ayub khan and Zia ul Haq Local Government System
}

\author{
Syed Shahid Zaheer Zaidi \\ Department of Public Administration, University of Karachi \\ Karachi, Pakistan.
}

\begin{abstract}
Pakistan is a country dominated by its military. In any such rule the government commences local government institutions in order to establish democracy at the core. In Pakistan the local government is the third branch of the regime and an integral part of the administration, because of its instrumental role in employing the ethics of democracy. Primarily study aims to examine and analyze the progress of Local Governments in Pakistan under the military regime of Ayub khan and Zia ul Haq. Secondarily, it is identifying the challenges faced by the system and to compare the similarities and differences between the local government systems.The local government system presented by Zia ul haq has some particular feature. Primarily, the provinces and the Federally Administered areas were given the freedom to make their own local government laws which led to the emergence of eight different ordinances. Secondly, for the rural and urban areas, same local government laws were made to avoid conflicts and to bring harmony in the rural and urban sectors by making it easy to comprehend. an invalidation of the guideline of democratic self-management in perspective of the inherent component of bureaucratic control which did not permit the delegate component to gain significant aptitude in the administration of local issues. To close, the period going before the destruction of Ayub Khan Regime, turned out to be a dim time in the historical backdrop of local government of Pakistan.
\end{abstract}

Keywords: Local Government, Military Regime, Political System

DOI: $10.7176 /$ PPAR/9-3-01

Publication date:March $31^{\text {st }} 2019$

\section{Introduction}

Historically, local government organizations are preceded by the national governments. For instance, in the IndoPak Sub landmass Panchayats, the Greek city-states and whatever is left of South Asia and the areas, districts and Parishes of England and America, they all have followed the convention of originating national, state or provincial governments. After the emergence of widespread interchanges frameworks and the sense of patriotism solidified, matters of local concerns have been given the elected or focal control which has led to the creation of more powerful local government frameworks which is different from elected or central governments, having special authorities and powers. The term local government is characterized as "that part of the administration of a state or nation which deals mainly with such matters as concern the inhabitants of a particular place or district, including those functions which the central government may consider desirable to be so administered."

A democratic society is one where there is mass participation by the citizens in the proposal, development and creation of laws. The implementation of this process is a crucial aspect of the local government. Thus, a stable system of local government is essential for a complete and democratic political system.

Pakistan is a country dominated by its military. In any such rule the government commences local government institutions in order to establish democracy at the core. In Pakistan the local government is the third branch of the regime and an integral part of the administration, because of its instrumental role in employing the ethics of democracy.

Local government generally acts within powers allotted to them by legislation or directives of the higher level of government. To truly understand the functions and structure of the local government various aspects have to be considered. With democracy being the heart of the local government, its basic agenda revolves around the formation of local public policy, council and their activities and the implementation of laws.

Local government is a vast term that cannot be applied to few fundamentals, thus defining it can be tiresome job. However, we can simplify it by saying that it is has its formal framework, a defined territory, institutions and limited powers to exercise within its allocated sphere. Furthermore, Montague Haris (1955, p. 4) in his book 'local government in many lands' has described it as "A system under which the people of the locality possess a certain responsibility and discretion in the administration of local public affairs and in the raising of money to meet their expenses".

The local government can exercise great deal of power in specific boundary. It can make decisions without notifying the higher authorizes. These authorities can only be imposed on the people belong to a prescribed boundary. According to United Nations, the local government or the local self-government refers to a political sub-division of a state, which is constituted by law and has substantial control of local affairs.

Moreover, the state must allow the local government to act without any interference from the state. The 
state must provide the local government with the authority to conduct public activities, to maintain peace and tranquility, work for development if the community, to collect the revenues and prepare budget.

The primary purpose of this study is to examine and analyze the performance of Local Governments in Pakistan under the military regime of Ayub khan Zia ul Haq, and identifying the challenges faced by the system and to check the similarities and differences between the local government systems.

\section{Local Government Under Ayub Khan's Era}

On 5th Oct 1958, a meeting was held between the president Iskandar Mirza and General Muhammad Ayub Khan regarding the nation's circumstances. As a result of the meeting, Mirza revoked the 1956 constitution on 7 th October 1958. Primarily, he broke up the assemblies and released the central and provincial governments. Secondly, he declared Martial Law with Ayub Khan being designated as the CMLA. After the declaration of Martial Law Ayub Khan proclaimed that, "There has been no limit to the depth of their (politicians) baseness, chicanery, deceit and degradation. The result is total administrative, economic, political and moral chaos in the country".

At the point when Ayub assumed control as the Chief Martial law Administrator and later on as President of Pakistan, he was completely persuaded that the political structure of the nation obliged a real upgrade. Ayub and his military partners were of the supposition that parliamentary framework did not suit Pakistan and would saddle the degenerate and defamed legislators go into force. The monetary and political turmoil which attempted Pakistan after autonomy persuaded the military pioneers that the Westminster Model did not suit the conditions and circumstances of Pakistan (Khan, 1967).

Ayub Khan to execute his impression of Pakistan's political request presented a framework that controlled majority rule government and guaranteed that his framework was the sort that individuals can comprehend and work capably. Ayub accepted that popular government in Pakistan ought to be of a sort that suits to the virtuoso of the individuals. In the first expression Ayub presents an arrangement of local self- government toward oneself in 1959 and issued the Basic Democracy (Jahan, 1972), request on the eve of the first celebration of the MARTIAL LAW regime. The arrangement of fundamental Democracy, prevalently known as BD framework with four levels was said to have been planned keeping in view the curious states of the nation to make the managerial methodology significant and to present vote-based system at grass-roots.

\section{Structure of Basic Democracy}

General Ayub Khan's Basic Democracy system was a quiet different plan that totally revamped the local government system of Pakistan. While analyzing this framework in depth, it uncovers the underlying complexities of the local government system. To initiate the analysis of its function, it was a "non-political" framework that it marked a progress of political speculation from rural to urban. It was responsible for the matters of welfare; security at all levels and aims to bring uniformity in the presidential framework and avoiding conflicts related to any political party. It also deals with the change of President's Electoral College, change in general political framework. Furthermore, it aims to spread developments, cooperation among the members and to shape a well regulatory popular government (Musarrat \& Azhar, 2012).

\section{Imperative Features of the System}

There are some important tasks dealt by this system. It aims to enhance the urban political presentation. It was determined to expand the political system of the country, while To decentralize the system of political power by making a balance in the political powers of urban and rural areas. Moreover, it also aims to strengthen the political power of the President while decreasing the role of regular political parties to make this framework free of political influence. In addition, it regulates the common political framework and forms provincial administration and large assembly at national level for the purpose of social reconciliation (Musarrat \& Azhar, 2012).

\section{Fundamental Democracies Organization}

The outline of the framework is pyramidal in nature. It is a five levels framework. Top to bottom arrangement of the basic democratic framework could be sketched out as takes after: 
Table 1: Local Government Framework Under Ayub Khan

\begin{tabular}{|c|c|}
\hline \multicolumn{2}{|r|}{ Level 5} \\
\hline $\begin{array}{l}\text { Principal Development } \\
\text { Advisory Councils }\end{array}$ & $\begin{array}{l}\text { \{members were delegated by the President on the proposal of provincial } \\
\text { governors\} }\end{array}$ \\
\hline \multicolumn{2}{|r|}{ Level 4} \\
\hline Divisional Level & $\{$ representative included from bureaucracy\} \\
\hline \multicolumn{2}{|r|}{ Level 3} \\
\hline District Level & $\{$ representative included from bureaucracy\} \\
\hline \multicolumn{2}{|r|}{ Level 2} \\
\hline \multicolumn{2}{|l|}{$\begin{array}{l}\text { Tehsil/ Thana (East Pakistan) } \\
\text { Level }\end{array}$} \\
\hline \multicolumn{2}{|r|}{ Level 1} \\
\hline Union \& Town Councils & \{pure individuals member participation $\}$ \\
\hline
\end{tabular}

At first the Basic Democracies framework included a five levels structure extending from its base in the rural Union councils and urban Union committees, through the Thana or Tehsil committee, to the district and divisional councils, at last two Provisional Advisory Councils. These were supplanted in 1962, compacted to four-level hierarchal structure of Union council/ Union committees, Tehsil Council/ town committee, District Council and Divisional Council.

\section{Local Government Under Zia ul Haq}

On $5^{\text {th }}$ July 1977, chief of the arm force, General Muhammad Zia ul Haq came into force. Being Chief Martial Law Administrator, he needed to hand over the authorities to the representatives of the country, Zia-ul-Haq guaranteed to hold National and Provincial Assembly elections in the following 90 days as the national and provincial assemblies were broken down; and political action was banned and 1973 constitution was abrogated. On the other hand, in October 1977 he introduced to begin an inspection procedure of the legislators because of the public interest for the examination of political pioneers who had been indulged in wrong practices in the past and elections were postponed. While tending to the country he stated that: "if we hold elections before completing the process of accountability, it will be a great injustice to the 70 million people of this country and if we accept that accountability should be completed first then the elections have necessarily to be postponed" (Saqib, 2009-10). The country was divided into five military administrative zones and serving Generals were appointed as a Martial Law Administrators. "The 1977 coup was by and largely welcomed by the bureaucracy" (Waseem, 1994).

\section{Local Government System 1979}

In 1979 General Zia-ul-Haq replaced the prior system with the Local Government Ordinance 1979 which was valid till some alterations made in 1995 (Anjum, 2005).

This newly introduced system of local government was the most effective in nature. After Bhutto, General Zia-ul-Haq revitalized local governments through the establishing Local government ordinances 1979 \& 1980. The new law presented two types of rural and three types of urban local government framework in the four provinces of the country (Quddus, 1981) and local bodies were chosen in all four provinces during 1979 and 1980 (Jalal, 1995). The councilors chosen from among themselves a Chairman \& a Vice Chairman. The Chairman acted as an executive head of the local council (Abid, 2004). Managerial and economic powers were centralized at the provincial and federal levels. In provinces named: Punjab, Sindh and KP, new Local Government Ordinance was promulgated in 1979, while in Baluchistan it was put into practice in 1980.

Under the new four levels government system, rural areas had three government levels; union council, tehsil council and district council, while, town committees, municipal corporation and city/metropolitan corporation operated in urban areas. Although politically important they were not complemented by any further decentralization of federal or provincial administrative functions or financial powers to the local level (Cheema, Khwaja, \& Qadir, 2005). For the first time in the history of Pakistan elections to all local councils were conducted on the basis of adult franchise.

The present local government system has some particular features. Primarily, the provinces and the Federally Administered areas were given the freedom to make their own local government laws which led to the emergence of eight different ordinances (burki), these were:

a) The Punjab Local Government Ordinance, 1979.

b) The Sind Local Government Ordinance, 1979

c) The NWFP Local Government Ordinance, 1979.

d) The Baluchistan Local Government Ordinance, 1980. 
e) The Capital Territory Local Government Ordinance, 1979.

f) The Northern Areas Local Government Ordinance, 1979.

g) The Azad Jammu and Kashmir Local Government Ordinance, 1979.

h) The Federally Administered Tribal Areas Local Government Regulation, 1979.

i) The Cantonments Act, 1924.

Secondly, for the rural and urban areas, same local government laws were made to avoid conflicts and to bring harmony in the rural and urban sectors by making it easy to comprehend. In order to follow the rules of policy laid down under the 1973 constitution, rights of representation were given to the minorities at the local council. Furthermore, all local councils have the newly elected chairmen and the process of elections was kept neutral on non-party basis (Mukerjee, 1989) and no selections on local councils were made. Moreover, Local councils were given the power to approve of their financial plans and tax proposals.

Surprisingly, there is a great deal of similarity is found in the structure of local councils in different parts of the country. In 1983, the second elections of local councils for the term of four years held and total 717137 members were elected. Amongst them to 4100 members were elected for the councils; 84 districts/agency councils, 12 municipal/metropolitan corporations, 117 municipal committees, 228 town committees and 39 cantonment boards. The interest of the candidates was manifest from the 215,000 nominations filed for 56356 Muslim seats i.e., four applicants per seats and 19.3 percent of the applicants were returned unimpeded.

Apart from this, to deal with the abnormalities of the election, the electoral laws associated with local government provided solutions and as a result petitions against elections were received the by election authorities in all provinces and Federally Administered regions.

\section{Structure of Local Government Urban Areas}

Local government structure has also under gone a change with the change in the prime proponent of the Martial law. Initially, local government system was introduced by Ayub Khan but soon changed and revived into an elected local government system by the second Martial Law Regime of General Zia. Akbar Zaidi in 2005 describes that according to the LGO 1979, in rural areas the local governments exists at three levels, i.e. Union Councils, Tehsil Councils and District Councils. While the middle part named Tehsil Councils was not significant, the Union Councils and District Council are considered the two main levels of local government. In contrast to the rural areas, local government in urban regions was based on four tiers namely, Town Committees, Municipal Committees, Municipal Corporations, and the Metropolitan Corporations in big cities Karachi and Lahore (Zaidi, 2005). The urban local government structure was again made similar to the 1958 structure with minute alterations (Azid \& Ayaz, 1991).

Muslim members of the union councils of about $80 \%$ were chosen by the elections based on adult permit, while the remaining $20 \%$ of the council seats were reserved for minorities like peasant workers tenants and women and each was given 5\% seats. Councilors selected the heads (chairmen and vice chairmen) of town committee as Electoral college. Moreover, union councils provided only two seats to women and $10 \%$ seats of District Councils, except in NWFP (Mumtaz, 2005).

Another significant characteristic of LGO 1979 was that it banned the direct representation of the bureaucracy in local governments. Consequently, provincial administration was left with a limited authority to regulate local government functions but still enjoyed the authority to adjourn the declarations of the local governments (Cheema, Khwaja, \& Qadir, 2005).

\section{Levels of Local Governments in Urban Areas}

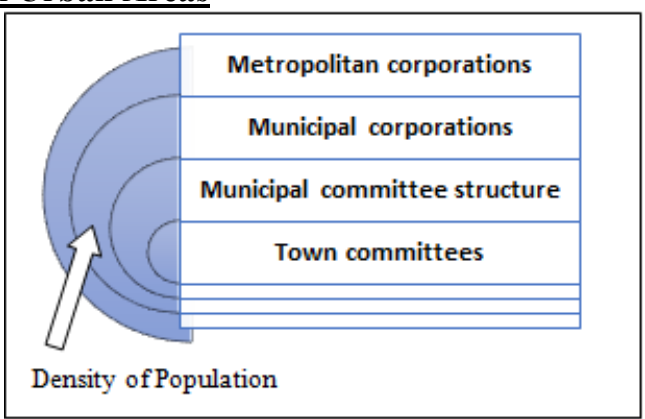

The two main tiers of the local government include Union Councils and District Council because the middle-tier, at the Tehsil/Taluka level, was brought to an end by the provincial government. Chairmen of these two councils were selected by the elected members of these councils. The managerial structure of the union council, town committee was based on three main departments: finance, engineering and general administration. Sector of health and education were created to uphold the work of the Municipal Corporation. However, in the two leading metropolitan corporations of Karachi and Lahore, organizational structure was based on some 
additional departments to deal with legal affairs, land management and development authorities acting as analogous organizations (Zaidi, 2005).

\section{Structure of Local government in Rural Areas} Levels of Local Government in The Rural Areas

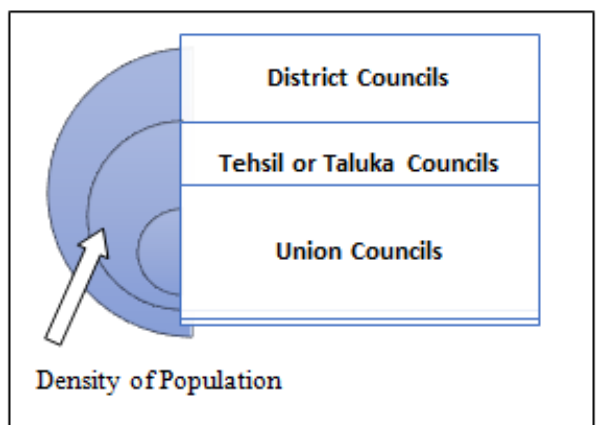

Due to the abolition of Tehsil level, only two institutions of local government i.e. union council and district council were functional in rural areas.

Total 4270 union councils functioned in the whole rural area of the country with an enrollment of eight to fifteen delegates, elected by the mature inhabitants of the village. Every elected member stood for $1000-1500$ of their kindred villagers. The chairman and vice chairman of Union Council had four years of service and was selected directly by the council members. While, the number of members relies upon the population of the council area concerned. The members included the elected representatives of people and women, workers, peasant minorities. A foreordained number of councilors were directly elected from the appointive division or wards in the district.

On the whole, this newly introduced system of local government was the most effective in nature. After Bhutto, General Zia-ul-Haq revived local governments through the propagating Local government ordinances 1979 and 1980.Although, Union councils, municipal committees and town committees vary in size but, surprisingly, based on similar regulatory systems. While the service tasks were under the assistance of local councils in urban regions.

This urban-rural separation leads to a kind of partiality to urban areas both in terms of local government income generation and expenditures. Under Zia's assistance, local governments were given due importance precisely by having adequate funds and hence Local government appear to work progressively. As a result, empowering the local government, a responsible committee was formed to perform managerial, advisory and other roles to firmly support the local government system in Pakistan.

\section{Conclusion}

Ayub Khan local government system was similar to the British period as local government system was controlled by the bureaucracy. The Essential Democracies framework was seen a substitute for all-inclusive suffrage and filled in as a Constituent School to choose the President and the congregations. Fundamental Democracies were concerned about close to local government and country progress. They were intended to give a two-way legitimizing channel of correspondence between the Ayub Khan routine and the common citizens. With an end to the Ayub Khan administration, his framework fell into disgrace and brought about the development of an overall arrangement of new government in the nation. Studies has revealed, that the first Martial Law Government successfully initiated the far-reaching system of local governments, however, the second General Zia's Martial Law administration devised the elected local governments. Like Ayub, Zia ul Haq made use of a policy of legalization and united political centralization at the national and provincial levels which gives rise to the establishment of the solitary local level electoral representation. In the year 1977-85 by putting Martial Law into practice, the administration attained Political centralization, which held the 1973 Constitution in abeyance which then pursued in 1985 by the 8th Constitutional Amendment.

The local government system presented by Zia ul haq has some particular feature. Primarily, the provinces and the Federally Administered areas were given the freedom to make their own local government laws which led to the emergence of eight different ordinances. Secondly, for the rural and urban areas, same local government laws were made to avoid conflicts and to bring harmony in the rural and urban sectors by making it easy to comprehend.

To conclude, the military government designated local bodies with a wide range of powers and function to transform the local bodies into an effective feasible organization for the purpose of dealing and solving the tribulations of the masses. As a result of empowering the local government, a responsible committee was formed to perform managerial, advisory and other roles to firmly support the local government system in 
Pakistan.

\section{References}

Anjum, N. (2005). Manual of New Punjab Local Government Laws with Punjab Local Government Ordinance 2001. Lahore: Mansoor Book House.

Azid, T., \& Ayaz, M. (1991). The Performance Profile of District Council Multan in the Sector of Education. Journal of Rural Development and Administration, 23(ii), 97-107.

Cheema, A., Khwaja, A., \& Qadir, A. (2005). Decentralization in Pakistan: Context, Contents and Causes. John F Kennedy School of Government. Harvard University.

Jahan, R. (1972). Pakistan: Failure in National Integration, New York: Columbia University Press.

Jalal, A. (1995). Democracy and Authoritarianism in Pakistan: A Comparative and Historical Perspective. Lahore: Sang-e-Meel.

Khan, A. (1967). Friends Not Masters: A Political Autobiography. London: Oxford University.

Mukerjee, D. (1989). Zia's Military Legacy. The Round Table (310), 179-191.

Mumtaz, K. (2005). Women's representation, effectiveness and leadership in South Asia. Paper presented at the fifth South Asia regional ministerial conference on the Celebrating Beijing Plus Ten. Islamabad.

Musarrat, R., \& Azhar, M. S. (2012). Decentralization Reforms in Pakistan During Ayub and Zia Era. Journal of Public Administration and Governance, 2(1).

Saqib, E. U. (2009-10). Pakistan Affairs. Lahore: Dogar.

Waseem, M. (1994). Politics and the State in Pakistan. Islamabad: National Institute of Historical and Cultural Research.

Zaidi, S. A. (2005). "The Political Economy of Decentralization in Pakistan" Tranversal Themes "Decentralization and Social Movements". Swiss National Centre of Competence in Research (NCCR). 